J. Perinat. Med.

2 (1974) 260

\section{Computed dip-parameters derived from digitized FHR-curves II. The value of descriptive parameters}

\author{
H. Albrecht, J. Bokelmann, J. Morgenstern, H. Schmidt \\ Universitäts Frauenklinik Düsseldorf (Head: Prof. Dr. L. BECk) \\ Düsseldorf/Germany
}

Received February 26, 1974. Accepted July 1, 1974.
The method of computing simultaneously and objectively numerous descriptive dip-parameters from digitized cardiotocograms (CTG) described in Part I, allows a closer investigation of the content of clinical information of single dipparameters. This work focuses on the following questions:

1. How do various dip-parameters behave in the cardiotocograms of normal newborns and of asphyxiated newborns?

2. Is the frequency distribution of certain dip-parameters a function of the lag-time or of the total area?

\section{Materials and methods}

From the year 1969 1,115 un-selected deliveries monitored by cardiotocography were analyzed retrospectively and coded. The code is based on 15 characteristics of identification and 19 clinical criteria. In order to define the state of the newborn not only by the APGAR score an extended newborn asphyxia index was utilized for the coding [4] (Fig. 1). Clinical portions of this newborn index are the APGAR score at 1,5, and 10 minutes, resuscitation measures, and the adaptation of the newborn in the first days of life. The asphyxia index defines three groups: Index 1 includes newborns without disturbances of adaptation, Index 2 newborns with a delayed adaptation and Index 3 identifies newborns with a severely disturbed adaptation up to serious asphyxia. According to this index the 1,115

\section{Curriculum vitae}

Dr. Herbert Albrecht was born in 1939 in Berlin. He studied medicine in Freiburg and Mainz from 1960 to 1966 and served a rotating internship from 1966-1968. He underwent training in neonatal intensive care at the Department of Pediatrics at the University of Diisseldorf, 1968 to 1969. He is an assistant at the Department of $\mathrm{Ob}$ stetrics and Gynecology at the University of Diisseldorf since 1969. His perinatal research focuses on the investigation of fetal beart frequency.

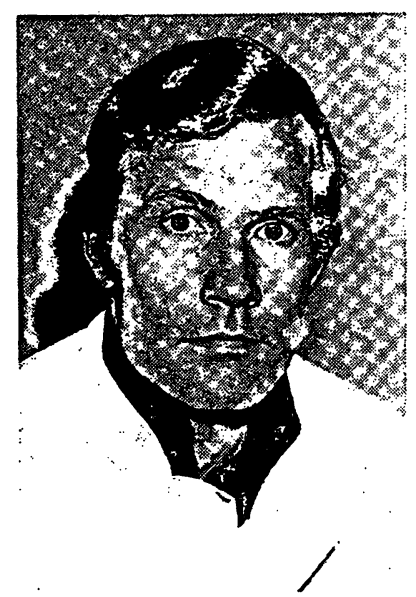

\begin{tabular}{|c|c|c|c|}
\hline Index & & APGAR score & Newborn condition \\
\hline 1 & $\begin{array}{l}\text { and } \\
\text { and }\end{array}$ & $\begin{array}{rr}1 \mathrm{~min} & 7-10 \\
5 \mathrm{~min} & 10 \\
10 \mathrm{~min} & 10\end{array}$ & $\begin{array}{l}\text { normal adaptation and no } \\
\text { clinical deterioration } \\
\text { no need of neonatal } \\
\text { intensive care }\end{array}$ \\
\hline 2 & $\begin{array}{l}\text { or } \\
\text { or }\end{array}$ & $\begin{array}{r}1 \mathrm{~min} 5-6 \\
5 \mathrm{~min} 7-9 \\
10 \mathrm{~min} 9\end{array}$ & $\begin{array}{l}\text { reanimation } \\
\text { no clinical deterioration } \\
\text { no need of neonatal } \\
\text { intensive care }\end{array}$ \\
\hline 3 & $\begin{array}{l}\text { or } \\
\text { or }\end{array}$ & $\begin{array}{r}1 \min 1-4 \\
5 \min 1-6 \\
10 \min 1-8\end{array}$ & $\begin{array}{l}\text { reanimation } \\
\text { insufficient adaptation } \\
\text { neonatal intensive care }\end{array}$ \\
\hline
\end{tabular}

Fig. 1. The extended newborn asphyxia index for the assessment of the newborn in the first 7 days of life. 
deliveries were divided into two groups with normal and pathologic newborn indices. The pathological group contains all digitized CTGs with a newborn index of 2 or 3 .

For the normal group with a newborn index of 1 , the selection of digitized cases was performed randomly until the number of CTG minutes was approximately equal to that in the pathological group.

The further evaluation comprised only those cases in which the CTG contained contractionrelated decelerations. Thus, in the normal group the number of patients was reduced to 105 with a total of 575 decelerations and the pathologic group to 46 patients with 367 decelerations. For each of the areas of deceleration, the 30 parameters described in Part I were available for further evaluation. From the multitude of descriptive parameters, only those parameters were selected with which informed clinicians are familiar and which are easily understood by others. Parameters thus examined are the area, amplitude, total duration, duration at half amplitude, decrement time, duration at dip minimum, recovery time, lag time, and fluctuation within the dip.
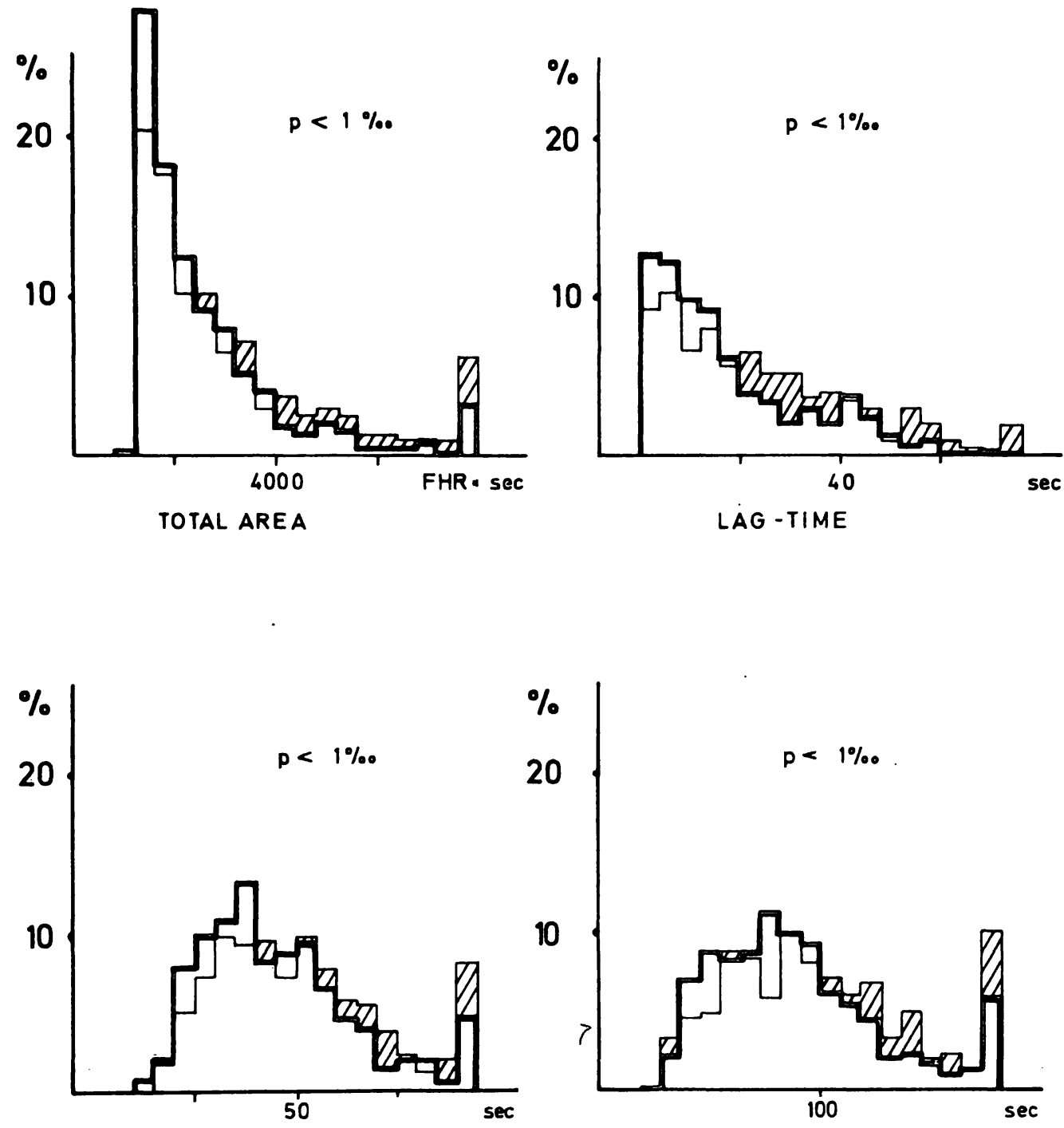

DURATION AT HALF AMPLITUDE

TOTAL DURATION

- NORM. INDEX 575 DIPS

Fig. 2. Frequency distributions of dip area, lag time, duration at half amplitude and total duration from digitized CTG tracings with normal and pathological newborn index. Each parameter has been divided into 20 samples of equal size. The normal group is drawn in bold face. 
The calculated values of each parameter were divided into 20 samples of equal size for the purpose of the study and graphically depicted in the form of frequency distributions. For the sake of easier understanding, the frequency distributions of the parameters of both groups were entered into the same graph. The distributions for the pathologic group are drawn in thin lines and those for the normal group in bold face. The deviations of the distributions for both groups are hatched. The variances in the frequency distributions of both groups for all parameters were tested with the chi-square test.

\section{Results}

\subsection{Frequency distributions of 9 descriptive} dip parameters

The frequency distributions for dip-area, lagtime, duration at half amplitude and total duration can be seen in Fig. 2. The parameters of area,
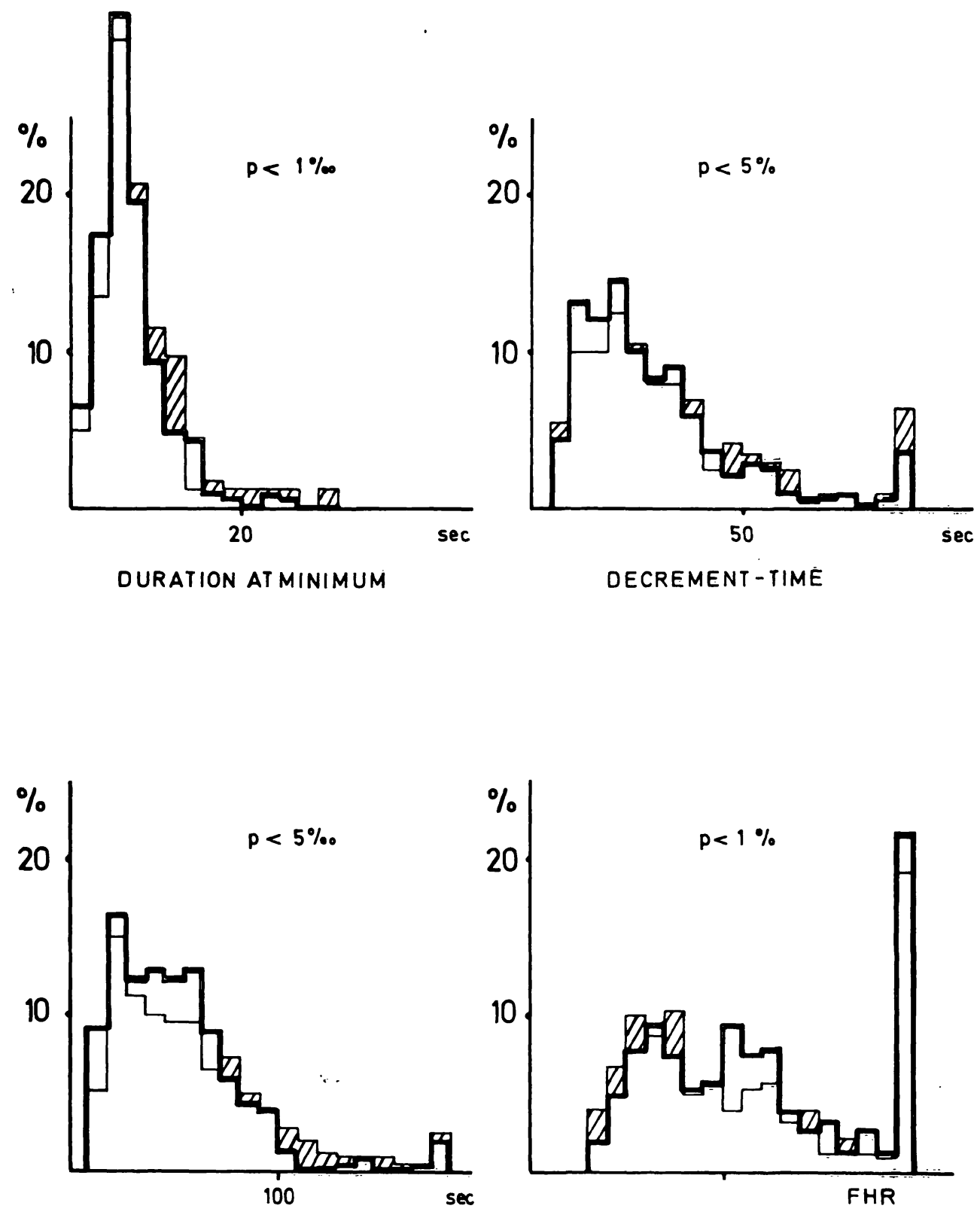

RECOVERY - TIME

FLUCTUATION WITHIN

$$
\begin{aligned}
& \text { - NORM.INDEX } 575 \text { DIPS } \\
& \text { — PATH.INDEX } 367 \text { DIPS }
\end{aligned}
$$

Fig. 3. Frequency distribution of decrement time, duration at minimum, recovery time, and fluctuation within the dip. 
total duration and duration at half amplitude show a shift towards high values in the CTG tracings with pathological newborn index. There appears to be a recognizable difference between the two groups relative to the lag-time $i$. e. dips with pathological newborn index contain more dips with a lag-time of over 20 seconds.

Fig. 3 demonstrates the distribution for duration at minimum, decrement time, recovery time and fluctuation within the dip. Except for the amplitude of the decrement, all examined parameters are significantly different between the two groups.

\subsection{The dependence of the dip parameter from lag-time and area}

The severity of CTG changes is judged by the clinician, particularly from the extent of the lagtime and the size of the dip area. For this reason it is logical to ask whether certain dip parameters leading to an abnormal neonatal adaptation change with increase of lag-time and area. It has been questioned whether decelerations with a large lag-time in the group with a pathological newborn index have a longer recovery time (i. e., the time between dip-minimum and base-Jine frequency) than decelerations with a short lag-
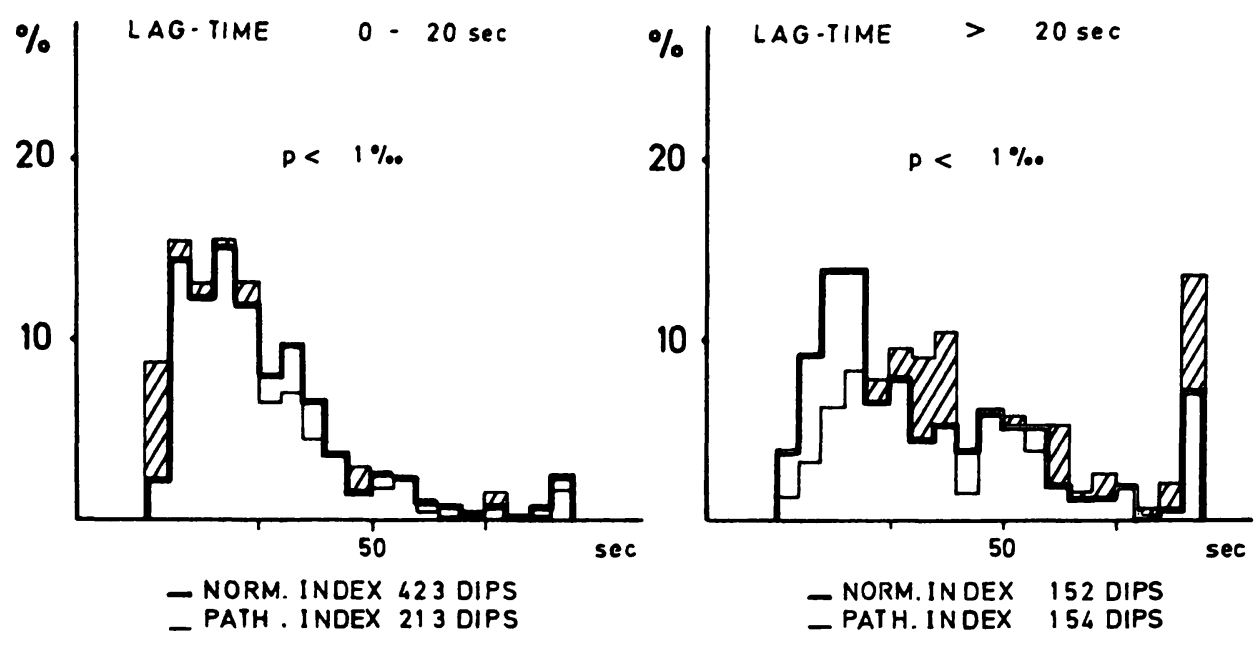

DECREMENT - TIME
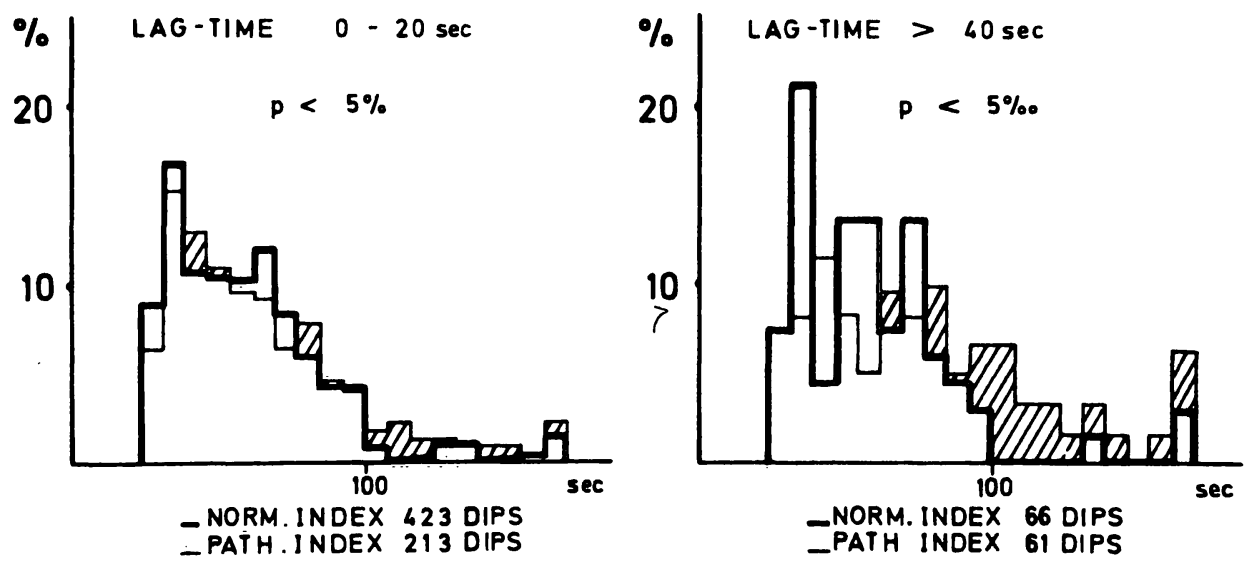

RE COVERY - TIME

Fig. 4. Frequency distribution for deceleration time and recovery time of decelerations with a small and a large lag time. 
time. With a lag-time over 20 seconds, higher decrement times are found more often in the group with a pathological newborn index. With a lag-time of over 40 seconds, the frequency distribution of the recovery times of the pathological group is markedly shifted to values with a longer recovery time. Furthermore, these large lagtimes (over 40 seconds) have more often an associated loss of the normal beat-to-beat variation. This is seen clearly in the frequency distribution for the fluctuation within the dip, with different lag-times (Fig. 4).

The dependence from the lag-time has been tested for all discussed parameters. Tab. I summarizes the results. The examined dip-parameters are listed in the left column of the table.

The first column lists the significant differences for all examined dip-parameters between the two groups without selection as to lag-times. The following three columns are based on limiting lag-times of $0-20,21-40$, and over 40 seconds. There was no correlation between lag-time and area, amplitude, and duration at minimum. CTGs with a pathological newborn index demonstrated a correlation between lag-time and recovery time, total duration and fluctuation within the dip.

The total area was examined similarly with a similar division of the total area in three groups. There was no alteration of the frequency distribution for certain parameters in the two groups. This means that in contrast to a long lag-time
Tab. I. The statistically significant differences $\left(X^{2}\right.$ test) of the frequency distributions of dip parameters in the groups with a normal and a pathological newborn index. Column 1 contains the significant differences for all decelerations. Columns 2, 3, and 4 contain significant differences for the decelerations with lag-times of $0-20,21-40$ seconds, and over 40 seconds. (An empty field denotes no significant differences.)

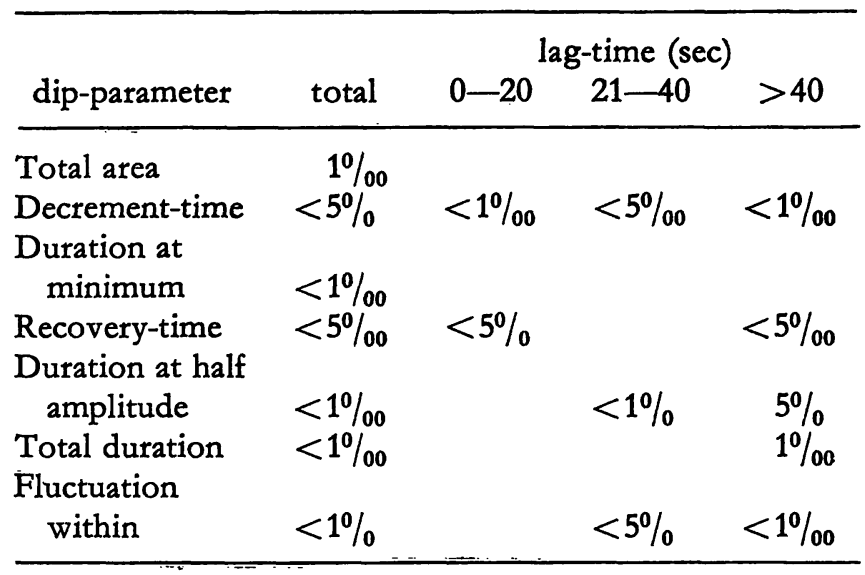

the fluctuation does not decrease with large total areas and a pathological newborn index.

\section{Commentary}

The interpretation of decelerations for the diagnosis of the fetal status is generally carried out according to CALDEYro-BARCIA [5] by type I and type II dips or by the deceleration types described by HoN [9] of head and cord com-
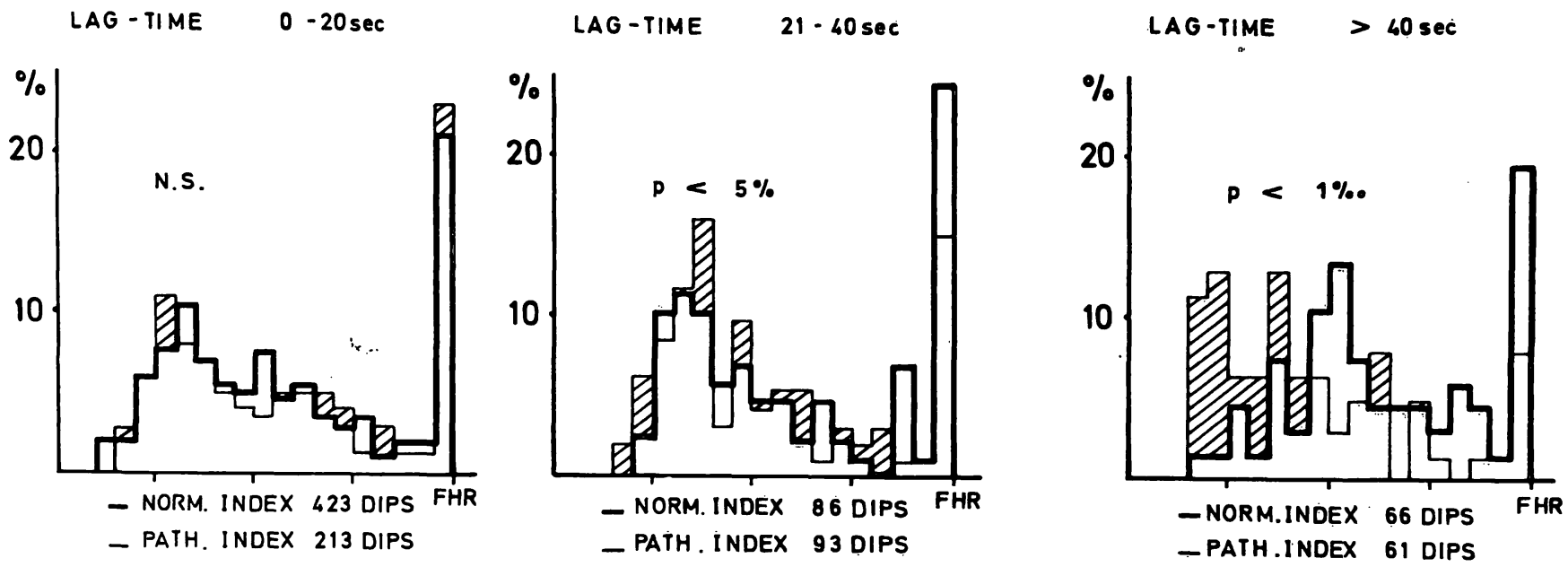

FLUCTUATION WITHIN

Fig. 5. Loss of fluctuation with increasing lag time. 
pression and utero-placental insufficiency patterns. The informational content of single dip parameters by which the decelerations may be differentiated by their form in regard to the occurrence of fetal distress, remains largely disregarded by these schemes, although many authors have pointed out the importance of duration of lag-time, amplitude, duration and number of preceding decelerations $[2,3,6,7,8$, $10,12,13,14,15,17]$. These authors found that there was a correlation between the increase of these dip-parameters and the degree of acidosis or state of the newborn. SHELLEY and Tipton [16] found that the decisive parameter for the assessment of the fetus was the sum of the total area of the dips.

While this did lead to a simplification of the interpretation of cardiotocograms, the power of a precise objective statement was lost because numerous important parameters such as the loss of fluctuation within the dip [7] was disregarded.

\section{Summary}

The frequency distribution of 9 descriptive parameters in cardiotocograms (CTG) in groups with normal and pathological newborn states was calculated and compared statistically. For the assessment of the state of the newborn an extended newborn asphyxia index was established which considers, in addition to the APGAR score at 1,5, and 10 minutes, the course of the newborn in the first 7 days of life (Fig. 1). The recorded CTGs were digitized and processed according to the method described in Part I. The group with a normal newborn index contains the digitized CTG tracings from 105 patients with 575 decelerations and the group with a pathological newborn index from 46 patients with 367 decelerations. It is shown that the CTG tracings with a pathological newborn index have significantly more decelerations with larger areas and larger lag-time, duration at half amplitude and total duration (Fig. 2), decrement time,
In order to interpret CTGs more objectively, Kimura [11] differentiated the distribution of the base line frequency, lag-time, amplitude, duration and recovery time of the deceleration as well as various fluctuation types of the base line frequency in samples with various Apgar and acidbase values. The examined FHR parameters were entered into an FHR score in order to assess the fetal state better.

Our examinations show that 8 of the 9 selected descriptive dip-parameters were significantly different in their frequency distributions between a normal and a pathological groups. This effect is reinforced for some parameters if only dips with a lag-time of over 40 seconds are selected for the examination. This particular result emphasizes the importance of the lag-time for the assessment of the state of the fetus. However, a rank order of importance for the examined descriptive parameters cannot be derived from our results.

duration at minimum, recovery time, and a decrease of the fluctuation within the dip (Fig. 3). For some of the examined parameters the difference in frequency distribution is even more marked in the two groups if only decelerations with a long lag-time are admitted (Fig. 4). With a lag-time of over 20 seconds, an increase of the decelerations with a large decrement time, total duration, and duration at half amplitude and CTG tracings with a pathological newborn index was found. Decelerations with a lag-time of over 40 seconds with a subsequent pathological post-partum adaptation are frequently characterized by a considerable loss in fluctuation (Fig. 5). The results show that for the interpretation of decelerations, many parameters must be considered. The relative importance for the assessment of the fetal state among the examined descriptive parameters cannot be derived from our results.

Keywords: Asphyxia index, dịitized data, electronic data processing, fetus, frequency distribution, parameters of deceleration.

\section{Zusammenfassung}

Computer-Auswertung von Dip-Parametern aus digitalisierten fetalen Herzfrequenz-Kurven. II. Die Bewertung deskriptiver Parameter

Es wurde die Häufigkeitsverteilung von 9 beschreibenden Dip-Parametern in Kardiotokogrammen '(CTG) mit normalem und pathologischem Neugeborenen-Zustand ermittelt und statistisch verglichen. Zur Beurteilung des Neugeborenen-Zustandes wird ein erweiterter Neugeborenen-Asphyxie-Index, der neben dem APGAR-Score nach 1, 5 und 10 Minuten den Verlauf des Neugeborenen in den ersten 7 Lebenstagen berücksichtigt, gebildet (Fig. 1). Die geschriebenen CTG's werden nach dem in Teil I dargestellten Verfahren digitalisicrt und ausgewertet. Das Kollektiv mit einem normalen NeugeborenenIndex enthält die digitalisierten CTG-Verläufe von 105 Patienten mit 575 Dezelerationen und das Kollektiv mit pathologischem Neugeborenen-Index, die von $46 \mathrm{~Pa}-$ tienten mit 367 Dezelerationen. Es zeigt sich, daß in 
CTG-Verläufen mit einem pathologischen Neugeborenen-Index signifikant häufiger Dezelerationen mit größeren Flächen, einer größeren lag-time, Dauer bei halber Dip-Tiefe, Gesamtdauer (Fig. 2), Abstiegszeit, Dauer im Dip-Minimum, Anstiegszeit und eine Einschränkung der Fluktuation im Dip (Fig. 3) vorkommen. Für einen Teil der untersuchten Parameter nimmt der Unterschied bezüglich der Häufigkeitsverteilungen in den beiden Kollektiven zu, wenn nur Dezelerationen mit einer großen lag-time zugelassen werden (Fig. 4). Bei einer lag-time ab $20 \mathrm{sec}$ wird eine Zunahme der Dezelerationen mit einer großen Anstiegszeit, Gesamt- dauer und Dauer bei halber Dip-Tiefe in CTG-Verläufen mit einem pathologischen Neugeborenen-Index gefunden. Dezelerationen mit einer lag-time über $40 \mathrm{sec}$, die eine Anpassungsstörung post partum zufolge haben, sind häufig durch einen erheblichen Fluktuationsverlust charakterisiert (Fig. 5). Die Ergebnisse zeigen, daß für die Beurteilung der Dezelerationen die Berücksichtigung vieler Parameter notwendig ist. Eine unterschiedliche Rangordnung für die Beurteilung des fetalen Zustandes läßt sich jedoch aus den untersuchten beschriebenen Parametern durch die gefundenen Ergebnisse nicht ableiten.

Schlüsselwörter: Asphyxie-Index, Dezelerationen, Dezelerations-Parameter, digitalisierte Daten, Elektronische Datenverarbeitung, Fet, Häufigkeitsverteilungen.

\section{Résumé}

Les paramètres Dip computés dérivés de courbes FHR digitalisées II. Valeur des paramètres descriptifs

Le présent article expose avec conftontation statistique la distribution de fréquence de 9 paramètres descriptifs en cardiotocogrammes (CTG) avec état normal et pathologique des nouveaux-nés. Pour l'appréciation de l'état du nouveauné, on a élaboré un index élargi d'asphyxie du nouveauné qui, à côté du Score APGAR après 1,5 et 10 minutes, suit l'évolution du nouveau-né durant les sept premiers jours (Fig. 1). Les CTG enregistrés sont digitalisés et évalués d'après la méthode exposée au chapitre I. Le groupe de l'index normal de nouveau-né comprend les tracés de CTG digitalisés de 105 patients avec 575 décélérations et le groupe de l'index pathologique de nouveauné ceux de 46 patients avec 367 décélérations. On observe dans les tracés de CTG avec index pathologique de nouveau-né des décélérations beaucoup plus fréquentes avec surfaces plus étendues, un lag-time plus grand, de même durée pour une demie profondeur Dip, la durée totale (Fig. 2), le temps de décroissance, la durée dans le minimum Dip, le temps de croissance et une restriction de la fluctuation dans le Dip (Fig. 3). Pour une partie des paramètres analysés, la différence relative aux distributions de fréquence dans les deux groupes augmente à condition seulement de décélérations avec un grand lagtime (Fig. 4). Pour un lag-time partant de $20 \mathrm{sec}$, on observe un accroissement des décélérations avec un temps de croissance, une durée totale et une durée pour demie profondeur Dip élevés dans les tracés de CTG avec index pathologique de nouveau-né. Les décélérations avec un lag-time supérieur à $40 \mathrm{sec}$, qui provoquent une adaptation pathologique post partum, se caractérisent fréquemment par une perte de fluctuation considérable (Fig. 5). Les résultats montrent la nécessité de tenir compte de beaucoup de paramètres pour pouvoir évaluer les décélérations. Les résultats obtenus à la suite de l'analyse des paramètres décrits ne permettent pas, toutefois, d' établir une classification différentielle pour l'appréciation de l'état foetal.

Mots-clés: Décélérations, distributions de fréquence, données digitalisées, foetus, index d'asphyxie, paramètre de délélération, traitement électronique des données.

\section{Acknowledgement}

This work was supported by the Bureau of Research, Ministry of Science and Research, State of Northrhine-Westphalia.

\section{Bibliographie}

[1] Albrecht, H., E. A. Stemmann, A. J. Waltke, U. SeidemanN: Die Bewertung perinataler Belastungsfaktoren für die Weiterentwicklung Neugeborener mit einer schweren Anpassungsstörung. Geburtsh. u. Frauenheilk. 32 (1972) 650

[2] Albrecht, H., J. Morgenstern: Ein Beitrag zur Frage der Korrelation der fetalen Herzfrequenz und Acidose unter der Geburt. In: Saling, E., J. W. Dudenhausen: Perinatale Medizin, Band III. 4. Deutscher Kongreß für Perinatale Medizin, Berlin 1971. Thieme, Stuttgart 1972
[3] Beard, R. W., G. M. Filshie, C. A. Knight, G. M. Roserts: The significance of the changes in the continuous fetal heart rate in the first stage of labour. J. Obstet. Gynaec. Brit. Cwlth. 78 (1971) 865

[4] Bokelmann, J., J. Morgenstern, H. Schmidt, H. Alrrecht: II. Kardiotokographische Befunde unter der Geburt bei einem Vergleichskollektiv. Geburtsh. u. Frauenheilk. 33 (1973) 931

[5] Caldeyro-Barcia, R., C. Mendez-Bauer, J. J. Poseiro, L. A. Escarcena, S. V. Pose, J. Bieniarz, I. Arnt, L. Gulin, O. Althabe: Control of human 
fetal heart rate during labor. In: Cassers, D.: The Heart and Circulation in the newborn and infant. Grüne and Stratton, New York 1966

[6] Caldeyro-Barcia, R., C. Casacuberta, R. Bustos, G. Grussi, L. Gulin, L. Escarcena, C. MendezBAUER: Correlation of intrapartum changes in fetal heart rate with fetal blood oxygen and acid base balance. In: Adamsons, K.: Diagnosis and Treatment Fetal Disorders. Springer, Berlin-Heidelberg-New York 1968

[7] Hammacher, K.: The clinical significance of cardiotocography. In: Huntingford, P. J., K. A. Hürer, E. Saling: Perinatal Medicine. 1st European Congress of Perinatal Medicine, Berlin 1968. Thieme, Stuttgart 1969

[8] Hoвel, J. H.: Intrapartum clinical assessment of fetal distress. Amer. J. Obstet. Gynec. 110 (1971) 336

[9] HoN, E. H.: An atlas of fetal heart rate patterns. Horty press Inc., New Haven 1968

[10] Hon, E. H., A. F. Khazin: Observations on fetal heart rate and fetal biochemistry. I. Base deficit. Amer. J. Obstet. Gynec. 105 (1969) 721

[11] Krmura, S.: Studies on fetal heart rate changes related to the conditions of fetus and newborn. Acta Obstet. Gynec. Jap. 18 (1971) 127

[12] Krause, W., G. Thiteme, H. Volkmer: Untersuchungen zur rechenautomatischen Auswertung gasanalytischer und elektronisch gewonnener Parameter sub partu. Z. Geburtsh. Perinat. 177 (1973) 129

[13] Kubli, F. W., E. H. Hon, A. F. Krazin, H. TakeMURA: Observations on heart rate and $\mathrm{pH}$ in the human fetus during labor. Amer. J. Obstet. Gynec. 104 (1969) 1190

[14] Mendez-Bauer, C., J. C. Arnt, L. Gulin, L. Escarcena, R. Caldeyro-Barcia: Relationship between blood pIt and heart rate in the human fetus during labor. Amer. J. Obstet. Gynec. 97 (1967) 580

[15] Morgenstern, J., H. Albrecht, J. Bokelmann, H. SCHMIDT: Computed dip-parameters dirived from digistized FHR-curves. Part I. The describing parameters and the method of digitizing. J. Perinat. Med. 2 (1974) 254

[16] Saling, E., J. W. Dudenifausen: The present situation of clinical monitoring of the fetus during labor. J. Perinat. Med. 1 (1973) 75

[17] Sinelley, T., R. H. Tipton: Dip area. A quantitative measure of fetal heart rate patterns. J. Obstet. Gynaec. Brit. Cwlth. 78 (1971) 694

[18] Wood, C., W. Newman, J. Lumley, J. Hammond: Classification of fetal heart rate in relation to fetal scalp blood measurements and Apgar-score. Amer. J. Obstet. Gynec. 105 (1969) 942

Dr. med. Herbert Albrecht Universitäts-Frauenklinik Moorenstraße 5 D-4000 Düsseldorf/Germany 